\title{
Pembinaan Konstruk Instrumen Penilaian Kendiri Akhlak Guru Pendidikan Islam Menurut Pandangan Pakar
}

\author{
Constructing The Constructs For The "Akhlak" Self-Assesment Instruments For The Islamic Education \\ Teachers From The Experts' Views
}

Salbiah Mohamed Salleh @, Salleh,a,*

a Fakulti Pendidikan, Universiti Kebangsaan Malaysia

*Corresponding author: salbiabukm81@gmail.com

\section{Article history}

Received: 2017-05-17 Received in revised form: 2018-02-12 Accepted: 2018-03-06 Published online: 2018-10-31

\begin{abstract}
This paper discusses the construction of the constructs for Instrumen Penilaian Kendiri Akhlak Guru Pendidikan Islam in the view of experts. These interviews were conducted on a purposive sample of 3 experts and an expert in the field of practice. The interview data were analyzed thematically using ATLAS.ti software. Base on the interview, the constructs for the instruments should include morals with God, human and environment. The moral construct with God consists of three sub - constructs of piety, sincerity and trust. Meanwhile, the construct with human is divided into seven sub - constructs; being fair, patient, loving, caring, forgiving, caring and gentle. Lastly, the moral construct with nature is divided into two sub - constructs that preserve and conserve nature. Based on the results obtained, the instrument 'Instrumen Penilaian Kendiri Akhlak Guru Pendidikan Islam' must include all the sub-constructs identified.
\end{abstract}

Keywords: Moral Instrument, Islamic Education Teacher, interview, experts

\begin{abstract}
Abstrak
Kertas kerja ini membincangkan tentang pembinaan konstruk Instrumen Penilaian Kendiri Akhlak Guru Pendidikan Islam menurut pandangan pakar. Temubual dijalankan kepada sampel bertujuan iaitu 3 orang pakar bidang dan seorang pakar praktis. Data temubual dianalisis secara tematik menggunakan perisian Atlas.ti. Hasil temu bual, didapati konstruk instrumen yang akan dibina hendaklah merangkumi akhlak dengan Allah, akhlak dengan manusia dan akhlak dengan alam sekitar. Konstruk akhlak dengan Allah merangkumi tiga sub-konstruk iaitu taqwa, ikhlas dan amanah. Manakala konstruk akhlak dengan manusia terbahagi kepada tujuh sub-konstruk iaitu adil, sabar, penyayang, prihatin, pemaaf, menjaga penampilan dan lemah lembut. Konstruk akhlak dengan alam terbahagi kepada dua sub-konstruk iaitu memelihara alam dan memulihara alam. Berdasarkan keputusan yang diperolehi, Instrumen Penilaian Kendiri Akhlak Guru Pendidikan Islam hendaklah mengandungi kesemua konstruk tersebut.
\end{abstract}

Keywords: Instrumen, akhlak, Guru Pendidikan Islam, temu bual pakar 


\subsection{PENDAHULUAN}

Guru merupakan arkitek sosial yang memberi sumbangan besar dalam pembangunan modal insan yang unggul. Agenda utama Kementerian Pendidikan Malaysia adalah untuk meningkatkan kualiti dan menjaga ketekalan kualiti guru seiring dengan cabaran transformasi sistem pendidikan negara. Maka, satu garis panduan iaitu Standard Guru Malaysia (SGM) telah dibina sebagai rujukan guru bagi memastikan mereka terus kompeten dalam bidang pendidikan. Tugas yang lebih berat digalas oleh Guru Pendidikan Islam (GPI) kerana mereka merupakan daie yang menyambung tugas para nabi dan rasul. Peranan GPI bukan sahaja memindahkan ilmu pengetahuan bahkan memindahkan nilai dan akhlak kepada pelajar. Justeru, peningkatan kualiti GPI hendaklah dimulai dengan pemantapan kualiti sahsiah dan akhlak ke arah mengintegrasikan potensi akliah, ruhaniah dan jasmani pelajar secara optimum.

\subsection{PERNYATAAN MASALAH}

Isu mengenai peranan guru sebagai agen akhlak merupakan fokus utama dalam pendidikan. Ini kerana guru yang mempunyai peribadi dan sahsiah yang terpuji mempunyai kaitan dengan pencapaian akademik pelajar (Kyllonen et al. 2014) dan mampu mempengaruhi prestasi kerja (alMahrooqi et al. 2015). Walau bagaimanapun kajian lepas menunjukkan peribadi guru masih berada di tahap sederhana (Salmah, 2004) dan terdapat guru yang kurang prihatin dan tidak adil melayan pelajar (Mahony 2009). Peranan GPI secara khusus sebagai qudwah hasanah juga turut diragui oleh segelintir masyarakat (Habibah \& Zaharah, 2014). Abdullah Sani et al. (2007) turut menyatakan kegagalan sebahagian GPI menonjolkan peribadi yang baik menyumbang kepada keruntuhan akhlak pelajar.

Terdapat pelbagai cara untuk meningkatkan mutu akhlak seseorang. Antaranya ialah dengan cara melakukan penilaian dan pentaksiran secara berterusan (Adibah, 2013). Penilaian kendiri akhlak merupakan satu stimulus untuk seseorang bertindak balas seterusnya melahirkan refleksi terhadap penilaian tersebut (Abdul Muhsien, 2014). Namun, setiap penilaian yang dilakukan memerlukan satu alat ukur yang sah dan boleh dipercayai. Isu kekurangan alat ukur berlandaskan agama Islam merupakan satu perkara yang dapat merencatkan proses pentaksiran akhlak (Almarri et al. 2009). Banyak kajian yang dilakukan telah mengadaptasi alat ukur yang dihasilkan dalam konteks agama lain seperti Judeo-Kristian (Md. Idris \& Saad, 2012). Justeru pembinaan instrumen pentaksiran akhlak berlandaskan sumber yang sahih dari sudut agama Islam sangat penting untuk mengatasi kelompangan yang wujud.

\subsection{KAJIAN PERPUSTAKAAN}

\subsection{Konsep Akhlak}

Akhlak merupakan kata jamak dari perkataan khuluq. Encyclopedia of Islam (1979) mendefinisikan akhlak sebagai pembawaan semula jadi. Kamus Munjid (t.t) dan Ibnu Manzur mempunyai kesamaan dalam menjelaskan maksud istilah akhlak iaitu sebagai budi pekerti, perangai, tabiat dan tingkah laku. Sementara Ensiklopedia Islam Safir (2000) menjelaskan khuluq dengan huraian yang lebih terperinci iaitu sebagai sifat maknawi manusia yang merangkumi sifat terpuji atau sifat keji.

Maksud akhlak secara umum ialah perbuatan dan tingkah laku yang ditonjolkan oleh manusia akhirnya akan muncul sebagai satu watak dan karektor yang kekal dalam diri seseorang. 
Namun al-Ghazali (1988) menghuraikan konsep akhlak sebagai amalan yang mengalami proses pembiasaan dan pengulangan. Kebiasaan tersebut akan kekal dalam diri seseorang yang akhirnya mudah untuk dipraktikkan dalam kehidupan seharian. Sebaliknya sebarang tingkah laku yang jarang dilakukan dan tidak dibiasakan dalam kehidupan seharian bukanlah merupakan contoh akhlak (Nik Azis, 2012).

Akhlak yang dianjurkan oleh Islam ialah akhlak yang menyeluruh. Sebagaimana Darraz (1987) membahagikan nilai akhlak Islam kepada lima kategori iaitu nilai akhlak peribadi, nilai akhlak kekeluargaan, nilai akhlak kemasyarakatan, nilai akhlak kenegaraan, dan nilai akhlak keagamaan. Manakala al-Ghazali (1988) meringkaskan keseluruhan akhlak manusia sebagai manifestasi tanggungjawab manusia bagi memenuhi hubungan asas dengan Allah, hubungan dengan manusia dan juga hubungan dengan alam sekitar. Setiap nilai yang melibatkan individu, kekeluargaan, kemasyarakatan dan kenegaraan akan melahirkan muslim yang sempurna di sisi agama.

\subsection{Instrumen Non-Kognitif Dalam dan Luar Negara}

Usaha untuk menghasilkan instrumen non-kognitif berasaskan agama Islam mula diberi perhatian secara serius oleh pengkaji dalam dan luar negara sejak kebelakangan ini. Sebagai contoh, Abu Raiya et al. (2008) telah menghasilkan instrumen Psychological Measure of Islamic Religiousness (PMIR). Instrumen ini mengandungi 70 item yang terdiri daripada 2 konstruk iaitu 21 item dimensi agama Islam dan 49 item dimensi agama umum. Dimensi agama Islam mempunyai 5 sub konstruk iaitu akidah, ibadah, suruhan agama, larangan agama dan kesejagatan ummah. Manakala konstruk dimensi agama umum pula mengandungi 7 sub konstruk iaitu pertukaran agama, penyelesaian masalah menggunakan agama, penyelesaian masalah dengan menyalahkan agama, keraguan dalam agama, identiti agama, adaptasi agama dan eksklusif dalam agama. Instrumen ini menggunakan pelbagai skala likert dari 3 mata sehingga 8 mata. Ujian rintis ditadbirkan kepada 64 orang muslim dari Amerika Syarikat dan kajian tinjauan menggunakan instrumen PMIR melibatkan 340 orang muslim di seluruh dunia menggunakan internet.

Pada tahun berikutnya Almarri et al. (2009) telah menghasilkan instrumen Short Muslim Practice and Belief Scale (Short MPBS) untuk mengukur tahap kepercayaan dan amalan beragama dalam kalangan penganut agama Islam. Instrumen ini kemudiannya diedarkan kepada 914 orang responden yang dibahagikan kepada dua kumpulan iaitu sampel dari negara Arab dan negara Asia. Instrumen yang dibangunkan mengandungi 13 item iaitu 7 item amalan beragama dan 6 item kepercayaan agama yang menggunakan skala 5 mata.

Di Malaysia, usaha awal dimulai oleh sekumpulan penyelidik dari Universiti Putra Malaysia iaitu Azimi Hamzah et al. (2006) untuk menghasilkan instrumen Muslim Religiosity and Personaliti Inventory (MRPI) bagi mengukur persepsi responden terhadap penghayatan beragama. Instrumen ini dibahagikan kepada dua bahagian iaitu Islamic Worldview Scale yang mengandungi 60 item dan Religious Personaliti Scale yang mengandungi 125 item. Instrumen ini mengukur penghayatan beragama individu. Instrumen ini tidak memfokus kepada penghayatan akhlak sepenuhnya tetapi lebih menjurus kepada penghayatan beragama.

Pada tahun yang sama juga, Azma (2006) telah menghasilkan Skala Penghayatan Pendidikan Islam (SPPIP-M) untuk mengukur tahap penghayatan Pendidikan Islam sekolah menengah. Tiga konstruk penghayatan Pendidikan Islam telah dibentuk iaitu tasawwur, perasaan dan tingkah laku. Instrumen yang dihasilkan mengandungi 254 item berasaskan kategori akhlak oleh Darraz (1987) berdasarkan Model Gable dan Wolf (1993). Item yang dibuat disemak oleh sekumpulan pakar dan instrumen mempunyai kebolehpercayaan yang tinggi iaitu nilai croanbach alpha yang 
diperolehi ialah antara 0.80 hingga 0.93. Analisis faktor juga turut dilakukan untuk mendapatkan kesahan konstruk. Kajian sebenar telah dijalankan ke atas 1074 orang pelajar dari 18 buah sekolah menengah di Selangor. Hasil kajian menunjukkan penghayatan Pendidikan Islam pelajar perempuan lebih tinggi daripada pelajar lelaki.

Jimaain (2012) pula telah menghasilkan Instrumen Pentaksiran Akhlak Berasaskan Rakan Sebaya Pelajar Sekolah Menengah (IPAM-RS) menggunakan klasifikasi akhlak oleh Darraz (1987) dan silibus akhlak Kurikulum Bersepadu Sekolah Menengah (KBSM) dan Kurikulum Bersepadu Sekolah Rendah (KBSR). Instrumen ini mengandungi 167 item yang terdiri daripada tujuh konstruk iaitu akhlak terhadap Allah, Rasul, diri, keluarga, masyarakat, alam sekitar dan negara. Analisis kesahan dan kebolehpercayaan instrumen dilakukan menggunakan Model Pengukuran Rasch.

Manakala, satu instrumen pengukuran akhlak pelajar Universiti Awam telah dibina oleh Adibah (2013). Instrumen Penilaian Akhlak Pelajar Institut Pengajian Tinggi (IMPAK) yang dibina berdasarkan teori peribadi Imam Ghazali, Teori Penaakulan Moral Kohlberg dan Teori Konstruktivisme. Instrumen ini mempunyai 64 item yang terdiri daripada tiga konstruk utama iaitu pertuturan, perilaku dan personaliti. Konstruk tingkah laku mempunyai 2 sub konstruk iaitu ekspresi pertuturan dan mesej pertuturan, konstruk komunikasi mempunyai 5 sub konstruk iaitu amanah, ihsan, sabar, rendah hati dan hubungan sosial, dan konstruk personaliti mempunyai 2 sub konstruk iaitu pemakaian dan kebersihan iaitu. Data dianalasis menggunakan Model Pengukuran Rasch dengan menilai kebolehpercayaan item dan individu, unidimensi, bias antara gender, dan kalibrasi skala.

Kajian terkini dijalankan oleh Mohamad Aziz Shah et al. 2015. Sekumpulan pengkaji dari Universiti Perguruan Sultan Idris (UPSI) ini telah membina Inventori Spiritual Imam al-Ghazali (ISIG) untuk mengukur tahap kesedaran, pengamalan serta pengetahuan responden terhadap nilai spiritual. Asas teoritikal pembinaan ISIG adalah berdasarkan 10 klasifikasi sifat mahmudah yang digariskan oleh Imam Ghazali. Instrumen ini mengandungi 10 konstruk dan setiap konstruk mempunyai 10 item. Kesahan kandungan diperolehi melalui penilaian 10 orang pakar dalam bidang spiritual. Walau bagaimanapun instrumen tersebut tidak melaporkan tahap kesahan konstruk dan kebolehpercayaan.

Kesimpulannya, cubaan membina instrumen non-kognitif berlandaskan sumber agama Islam merupakan satu usaha berterusan yang dilakukan oleh pengkaji muslim dalam dan luar negara pada masa kini. Pendekatan dan skop atribut yang berbeza memberikan satu kepelbagaian yang positif ke arah mewujudkan satu alat ukur yang mematuhi ciri psikometrik. Kesannya, setiap alat ukur yang dibina boleh digunakan secara meluas dalam pelbagai kajian merentasi bidang samada dalam bidang pendidikan atau psikologi.

\subsection{OBJEKTIF DAN PERSOALAN KAJIAN}

Kajian ini bertujuan untuk membina konstruk instrumen Penilaian Kendiri Akhlak Guru Pendidikan Islam berdasarkan pendapat pakar.

\subsection{Persoalan Kajian}

1. Apakah konstruk Instrumen Penilaian Kendiri Akhlak Guru Pendidikan Islam berdasarkan pendapat pakar?

\subsection{METODOLOGI}


Kajian ini menggunakan pendekatan kualitatif dengan menggunakan temu bual separa berstruktur terhadap pakar bagi mendapatkan konstruk yang sesuai untuk digunakan dalam Instrumen Penilaian Kendiri Akhlak GPI. Kaedah temu bual pakar merupakan langkah penting untuk mendapatkan maklumat tentang konstruk yang sesuai digunakan untuk pembinaan instrumen. Czaja dan Blair (1996) menjelaskan pakar hendaklah terdiri daripada tiga hingga lima orang yang terdiri daripada pakar bidang dan pakar praktis. Kekuatan menggabungkan pemilihan pakar ialah dapat mengumpul maklum balas daripada pelbagai kepakaran serta mampu mewujudkan hasil kerja yang lebih jitu (Bassili,1996).

Sampel yang terlibat dalam proses menentukan konstruk instrumen ialah seramai empat orang pakar. Sampel ini dipilih secara bertujuan (purposive) dalam kalangan mereka yang berpengalaman dan mempunyai kepakaran dalam bidang akhlak. Justeru, seramai empat orang pakar telah dipilih untuk ditemubual iaitu tiga orang merupakan pakar bidang dan seorang merupakan pakar praktis. Bagi tujuan kajian ini, individu yang dipilih sebagai pakar mempunyai kriteria yang telah ditetapkan seperti berikut:

a) Golongan profesional yang memiliki pengalaman bekerja melebihi sepuluh tahun sebagai pensyarah di universiti

b) Ahli akademik yang mempunyai kepakaran dalam bidang akhlak dan menghasilkan banyak kajian tentang Guru Pendidikan Islam

c) Terlibat secara langsung untuk pemantapan kompetensi Guru Pendidikan Islam

d) Memberi persetujuan untuk ditemubual

Analisis data temu bual dilakukan sebaik sahaja pengumpulan data dilaksanakan. Penyelidik melakukan sendiri analisis temu bual untuk meningkatkan kefahaman terhadap data kajian. Hasil rakaman temubual, penyelidik telah melakukan transkrip dan menyerahkan kembali transkrip temu bual untuk disahkan oleh pakar. Transkrip temu bual yang telah disahkan dianalisis menggunakan perisian Atlas.ti dengan menggunakan proses open coding. Proses open coding dilakukan bagi mengenal pasti konstruk yang sesuai digunakan untuk pembinaan instrumen penilaian kendiri akhlak GPI. Seterusnya proses axial coding digunakan dengan menghubungkan konsep-konsep tersebut kepada tiga kategori utama (tema) konstruk akhlak Guru Pendidikan Islam. Proses yang terakhir ialah proses selective coding iaitu dengan menghubung jalin tema yang diperolehi dengan teori dan analisis dokumen yang telah dilaksanakan.

\subsection{DAPATAN KAJIAN}

Dapatan kajian ini memberi fokus untuk menjawab persoalan yang ditentukan berdasarkan objektif kajian yang telah ditetapkan iaitu pendapat pakar tentang konstruk yang sesuai digunakan untuk mengukur akhlak Guru Pendidikan Islam. Berdasarkan analisis yang dibuat, instrumen akhlak Guru Pendidikan Islam yang dibina merangkumi konstruk berikut iaitu:

a) Akhlak dengan Allah yang merangkumi sifat amanah, ikhlas dan taqwa

b) Akhlak dengan manusia yang merangkumi sifat kasih sayang, sabar, adil, lemah lembut, menjaga penampilan, pemaaf dan prihatin.

c) Akhlak dengan alam yang merangkumi memelihara dan memulihara alam

\subsection{Konstruk pertama: Akhlak dengan Allah}

Akhlak Guru Pendidikan Islam yang paling utama ialah menjaga hubungan dengan Allah iaitu dengan cara ikhlas menjalankan tugas, amanah dengan tugas, masa dan ilmu serta bertaqwa kepada Allah.

Page $\mid 5$ 
Menurut Pakar 2: Bagi saya guru mesti jaga bubungan dengan Allah. Guru perlu amanah, ikblas dan tanam sifat taqwa dalam diri

Akhlak dengan Allah merupakan peringkat akhlak yang paling tinggi (Mohd Nasir, 2005. Hubungan dengan Allah hendaklah dijaga oleh setiap hamba dengan cara taat melakukan perintahNya dan meninggalkan segala jenis dosa dan maksiat. Hal ini dijelaskan dengan lebih lanjut oleh Pakar 1 berkenaan hubungan dengan Allah:

Guru ni kena konsisten buat benda yang baik, perlu hindari benda mungkar. Kena betulbetul jaga tingkah laku

Dalam konteks akhlak guru, mereka hendaklah melakukan tugasan mendidik dengan penuh keikhlasan tanpa mengharapkan balasan serta mengelakkan diri daripada bersifat dengan sifat riya', ujub dan takbur (Yunahar, 1999). Sebagaimana yang dijelaskan oleh Pakar 2 tentang sifat ikhlas yang perlu ada pada setiap guru:

Pakar 2 juga turut menjelaskan konsep ikhlas seorang guru:

Contoh kalau kita nak ukur guru ikhlas atau tak. memang benda ni tak nampak. Tapi kita boleh ukur dengan tanya adakah anda sanggup berkorban untuk Islam, adakah anda sanggup bekerja walaupun tanpa bayaran atau adakah anda sanggup kerja lebih masa

Pakar 4 pula menyarankan guru perlu berpegang teguh dengan sifat amanah dalam melaksanakan tugas dengan cara amanah dengan tugasan dan ilmu yang ada.

Guru ni kena amanah. Besar tanggung jawab guru ni. Lagi la Guru Pendidikan Islam. Kena jaga masa mengajar, jangan menghukum luar dari ilmu kita. Sebab kita contoh masyarakat

\subsection{Konstruk kedua: Akhlak dengan Manusia}

Seorang guru merupakan arkitek sosial yang sentiasa terlibat dengan muamalah sesama manusia samada dalam pekerjaan mahupun kehidupan seharian. Tingkah laku yang baik sesama manusia hendaklah dipelihara supaya kehidupan lebih harmoni (Mohd Nasir, 2005). Dalam organisasi pendidikan, hubungan yang wujud ialah hubungan antara guru dengan pentadbir, hubungan guru dengan rakan sekerja dan hubungan guru dengan pelajar (Kamarul Azmi, 2010). Untuk mewujudkan ikatan hubungan yang mapan, guru hendaklah menyantuni dengan akhlak yang mulia seperti kasih sayang, sabar, adil, lemah lembut, prihatin, menjaga penampilan dan pemaaf.

Hal ini dijelaskan dengan lebih lanjut oleh Pakar 3 iaitu : Cikgu ni kena jaga betul bubungan dengan pelajar dia, dengan pemimpin. Maksudnya pengetua dia, pentadbir dia. Lagi satu dengan ibu bapa pelajar, rakan sekerja, masyarakat. Dalam Ibya' Ulumuddin ni memang sebut cara guru berinteraksi dengan murid, cara berinteraksi dengan guru dengan ibu bapa murid.

Kasih sayang merupakan sifat asas yang perlu ada pada setiap guru untuk mewujudkan hubungan baik antara guru dengan murid (Alkanderi, 2001). Hubungan yang wujud antara guru dengan pelajar umpama hubungan ibu bapa dan anak (Nasih Ulwan 1979; al-Ghazali 1988). Guru yang mempunyai sifat keibuan akan berusaha mendidik dan membimbing pelajar dengan penuh kelembutan dan prihatin manakala sifat kebapaan pula akan menterjemahkan kewibawaan dan kepimpinan dalam diri guru (Nasih Ulwan, 1979). Pakar 1 dan Pakar 4 menjelaskan sifat kasih sayang menjurus kepada kasih sayang guru kepada murid :

Pakar 1: Contoh dalam kelas dia sayang pelajar dia.. kat luar kelas pun dia sayang pelajar dia 
Pakar 4: Imam Ghazali sebut kasih sayang guru kepada murid melebibi kasih sayang ibu bapa kepada anakanaknya. Kerana guru ni dia nak selamatkan murid dari api neraka sedangkan ibu bapa cuma nake selamatkan anak dari bencana dunia

Guru Pendidikan Islam juga disaran untuk bersifat adil ketika melayan murid tanpa membezakan pelajar. Layanan hendaklah diberikan secara sama rata berlandaskan ajaran alQuran dan sunnah supaya tiada murid yang tersisih atau dipinggirkan. Guru juga hendaklah menyantuni sifat sabar dengan menahan diri daripada sifat marah kerana murid merupakan insan yang tidak mengerti dan lemah (al-Ghazali, 1988). Pengajaran yang diberikan hendaklah dilakukan dengan lemah lembut tanpa menggunakan kekerasan. Ini dijelaskan Habibah \& Zaharah (2014) yang menerangkan pengajaran merupakan satu kemahiran yang memerlukan strategi dan kebolehan mengendalikan emosi dengan baik disulami kelembutan dan kesopanan.

Pakar 2: Kita ustaz, ustazah kena jaga perkataan kita, marab kita, aib kita. Sebab budak-budak akan pandang. Dia akan tengok.

Pakar 4: Ada cikgu pandai mengajar tetapi tak pandai berkomunikasi dengan murid. Ada cikgu baik dengan murid tapi tak pandai mengajar. Jadi sebenarnya cikgu yang baik ialah mengajar pun baik, tingkah laku pun mesti baik. Keduanya perlu seimbang.

Pakar 4: Guru ni perlu adil layan murid supaya tak timbul isu kecik. hati atan terpinggir

Seorang guru juga disaran untuk prihatin dengan sentiasa memerhati dan peka dengan kelemahan dan kekuatan yang ada pada setiap pelajar. Implikasinya, guru boleh mengatur strategi pengajaran tertentu mengikut kesesuaian akal pelajar (al-Ghazali, 1988). Abdullah Sani et. al (2007) menjelaskan sifat pemaaf guru ialah guru yang dapat menerima kesalahan murid dengan hati yang terbuka. Guru juga perlu bersedia memaafkan murid sekiranya mereka melakukan kesilapan. Mohd Aderi et al. (2015) menjelaskan sifat penyabar, penyayang, prihatin dan lemah lembut merupakan elemen penting yang digunakan dalam pendekatan dakwah Rasulullah (saw). Berdasarkan temu bual pakar, mereka bersepakat dengan sifat adil, sabar dan lemah lembut seperti yang dijelaskan:

Pakar 4: Guru kena kuat untuk maafkan kesalahan murid. Adatlah murid buat salah. Tapi cikgu kena kuat, bati kena lapang

Pakar 3: Tengok betul-betul budak yang kita ajar. Mungkin ada hari dia tak makan, atau ada masalah keluarga. Sape tau. Di sinilah tanggung jawab guru. Sebelum minta bome work, kena selidik dulu pelajar..perlu kenal pelajar dengan baike

Aspek terakhir yang perlu ada pada setiap Guru Pendidikan Islam ialah menjaga penampilan dengan cara menutup aurat dengan sempurna tanpa mengabaikan aspek kebersihan dan kekemasan diri. Guru hendaklah menjaga penampilan yang merangkumi rupa paras, penampilan fizikal dan penampilan sosial. Pakar 1 menjelaskan tentang penampilan diri guru sebagaimana berikut :

Contohnya guru kena tutup aurat. Jaga penampilan dengan baik. Cara pakai, cara bercakap semua kena konsisten. Di sinilah kita ukur dia

\subsection{Konstruk ketiga: Hubungan dengan Alam}

Kesempurnaan akhlak kepada diri seseorang meliputi seluruh dimensi kehidupan. Hubungan manusia tidak terhad kepada hubungan dengan pencipta sahaja tetapi lebih menyeluruh meliputi 
makhluk lain seperti manusia dan alam semesta. (Mohd Nasir, 2005). Dalam konteks pendidikan, tugas sebagai seorang guru menuntut GPI menjalankan tanggungjawab yang menyeluruh termasuk sebagai contoh ikutan dalam mentadbir dan menguruskan alam. Standard Guru Malaysia (SGM) meletakkan satu aspek penilaian khusus untuk menilai tanggungjawab guru terhadap alam (Kementerian Pendidikan Malaysia, 2014). Alam merupakan unsur yang merangkumi haiwan, tumbuh-tumbuhan dan benda keras seperti kayu, logam dan batu.

Beberapa orang pakar menjelaskan aspek pemeliharaan dan pemuliharaan alam yang mesti dijaga oleh setiap GPI.

Pakar 4: Contoh cara cikgu duduk di kerusi..itu menunjukkan kerusi tu boleb diguna lama atau tidak. Contoh kalau tidak tunjukekan cara jaga alam dengan betul mana nak dapat kertas, mana nak dapat perabot. Contoh dalam hadis Nabi seorang lelaki yang jahat tetapi dia memberi minum pada anjing, maka dia masuk syurga.. Haa.ini menunjukkean kalau kita berbuat baik dengan binatang sekalipun, ini dikira amalan yang baik. Jadi kalau di sekolah kita boleh tengok cara cikgu manfaatkan sumber yang ada pada dia untuk. kebaikan.

Pakar 4: Maksud menjaga alam ni untuk guru. Mereka mesti tunjukkean, dari aspek peranan keseluruban, murid nak tengok macam mana guru menguruskan aspek alam. Macam mana guru berakblak dengan alam. Ini bermaksud tidak merosakean alam, tidak memusnabkan binatang dan tumbuban. Kemudian dari segi menjaga alam ini dengan betul..ni memanfaatkan alam.

Pakar 3: Dengan alam ni tak banyak. Dia ada memelihara alam, memulibara alam. Tengok ada tiga bubungan yang berkaitan dengan alam. Hubungan dengan bayawan dengan baiwan, nabatat tumbuh-tumbuban, jamadat benda keras, benda rigid macam batu, kayu, api, air. Jadi bubungan manusia dengan alam ni dibahagikan kepada tiga hayawan, nabatat dan jamadat. So, cara dia jangan rosakkan alam, menjaga alam, memelihara alam, memulibara alam. 


\subsection{DAPATAN KAJIAN DAN PERBINCANGAN}

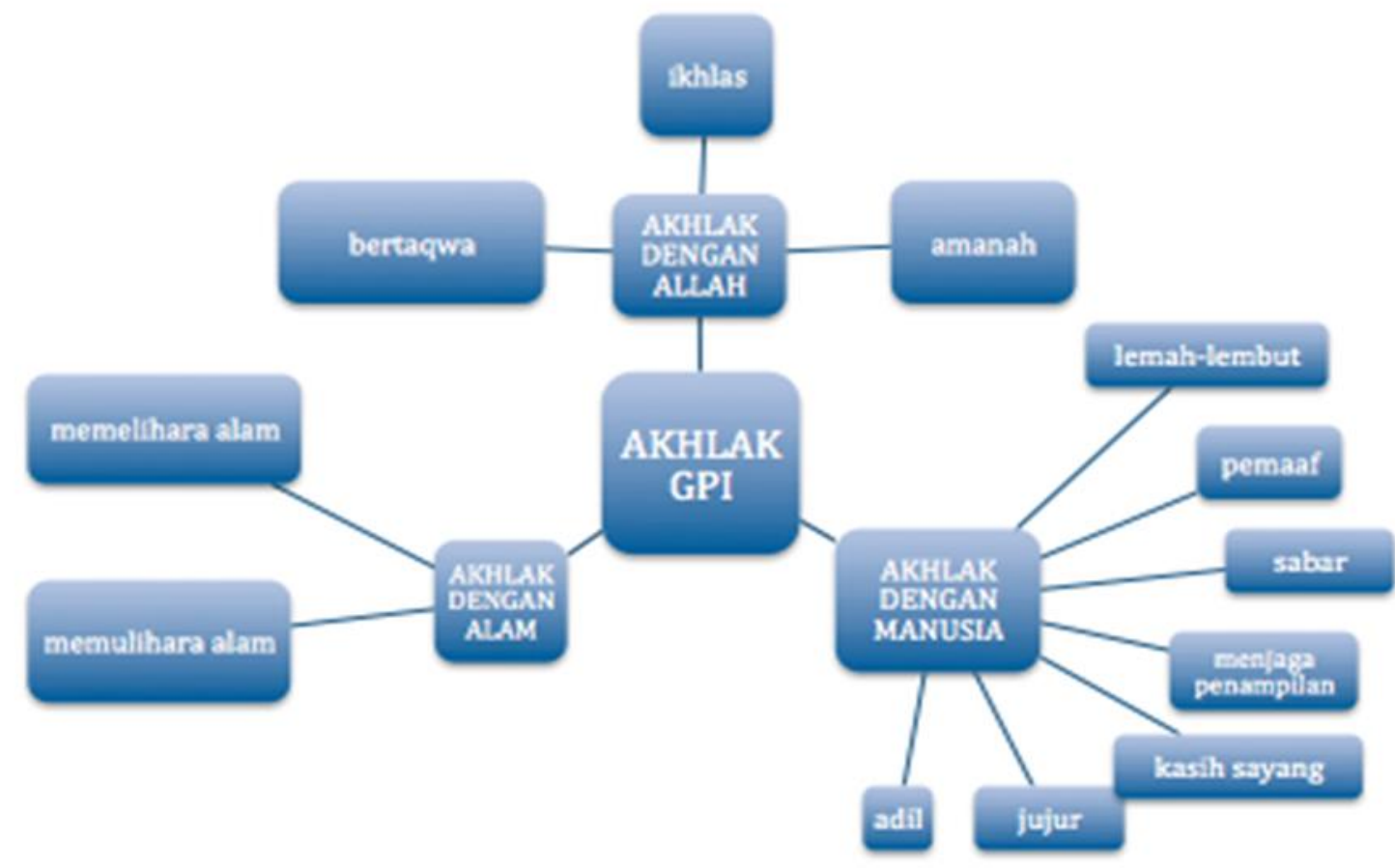

I

\section{Rajah 1: Model Akhlak Guru Pendidikan Islam Berdasarkan Temu Bual Pakar}

Rajah 1 merupakan rumusan dapatan berdasarkan temu bual pakar yang telah dilaksanakan. Dapatan kajian terhadap temu bual pakar kesemua pakar bersetuju bahawa Instrumen Penilaian Kendiri Akhlak GPI hendaklah merngandungi konstruk akhlak dengan Allah, akhlak dengan manusia dan akhlak dengan alam. Bagi konstruk akhlak dengan Allah, pakar bersetuju bahawa hubungan dengan Allah sangat penting untuk dipelihara oleh Guru Pendidikan Islam. Hal ini selari dengan dapatan kajian Habibah dan Zaharah (2014) yang menjelaskan GPI perlu mendidik jiwa dengan nilai-nilai kerohanian bertunjangkan keimanan dengan Allah. Pakar bersetuju bahawa GPI hendaklah berusaha melakukan suruhan Allah dan meninggalkan larangan Allah dalam konsep taqwa. GPI juga menjalankan tugas mengajar dengan ikhlas tanpa mengharapkan balasan seterusnya bersifat amanah dengan tugasan, ilmu dan masa mengajar yang telah diperuntukkan.

Seterusnya pakar bersepakat dengan aspek menjaga muamalah dengan manusia. Namun Pakar 3 menghuraikan dengan lebih lanjut aspek akhlak dengan manusia yang perlu dipelihara oleh GPI merangkumi hubungan dengan pentadbir, rakan sejawat, pelajar dan masyarakat. Seterusnya sub-atribut bagi akhlak dengan Allah merangkumi sifat adil, sabar, penyayang, prihatin, lemah lembut, pemaaf dan menjaga penampilan. Aspek kasih sayang diulang oleh Pakar 1 dan pakar 4 bagi menunjukkan kepentingan keutamaan kasih sayang dalam mendidik pelajar. Hal ini turut dihujahkan oleh Abdul Muhsien (2014) dan Alkanderi (2001) yang menjelaskan hubungan dengan pelajar hendaklah dibina berdasarkan sifat kasih sayang, prihatin, adil dan kelembutan.

Konstruk ketiga yang dipersetujui oleh pakar ialah aspek akhlak dengan alam. Pakar 3 menjelaskan konsep alam yang terdiri daripada alam hayawan (haiwan), alam nabatat (tumbuhan) dan alam jamadat (benda rigid dan keras). Pakar 4 pula menjelaskan contoh-contoh yang boleh 
diamalkan oleh GPI untuk menjaga alam ke arah kelestarian alam sekitar. Konstruk menjaga alam juga merupakan antara item dalam Standard Guru Malaysia ke arah mewujudkan satu standard guru berkualiti yang perlu dipenuhi oleh setiap guru.

Oleh itu, jelas menunjukkan Instrumen Penilaian Kendiri Akhlak GPI hendaklah mengambil kira konstruk akhlak dengan Allah, akhlak dengan manusia dan akhlak dengan alam bagi mewujudkan keseimbangan sahsiah rohani dan jasmani seorang pendidik. Item yang dibina pula hendaklah berlandaskan panduan al-Quran dan hadis serta kitab muktabar daripada ulama' Islam. Inilah punca kekuatan pendidikan akhlak yang ditekankan oleh Islam kerana bersumberkan kepada dalil naqli yang utuh (Mohd Aderi et al. 2015). Pembinaan item bersumberkan wahyu dapat menjadikan instrumen yang dibina lengkap dan sesuai digunakan pada bila-bila masa.

\subsection{KESIMPULAN}

Pembinaan instrumen akhlak berlandaskan sumber yang sahih dalam agama Islam merupakan satu keperluan ke arah peningkatan kompetensi GPI. Peribadi GPI memberi pengaruh untuk mewujudkan pembelajaran berkesan dan meningkat penghayatan akhlak murid. Justeru, penilaian kendiri merupakan langkah yang boleh digunakan untuk GPI melakukan muhasabah seiring dengan tuntutan agama. Temubual pakar merupakan langkah awal bagi memastikan konstruk yang digunakan untuk membina instrumen sesuai dan sah.

\section{Rujukan}

Abdul Muhsien Bin Sulaiman. (2014). Peranan Guru Pendidikan Islam Dalam Pembentukan Akhlak Murid Dari Aspek Hubungan Guru-Murid Berasaskan Abu Talib Al-Makki (W.386h/996m), Tesis Phd UM

Abdullah Sani Yahya, Abdul Rashid Mohamed \& Abdul Ghani Abdullah. (2007). Guru Sebagai Pemimpin. Kuala Lumpur: PTS Professional Publishing Sdn. Bhd.

Abu Raiya, H., Pargament, K. I., Mahoney, A. \& Stein, C. (2008). A Psychological Measure of Islamic Religiousness: Development and Evidence for Reliability and Validity. International Journal for the Psychology of Religion, 18(4), 291-315. doi:10.1080/10508610802229270

Adibah bt Abdul Latif. (2013). Pembangunan instrumen penilaian akhlak pelajar di institusi pengajian tinggi awam. Tesis Phd. Universiti Teknologi Malaysia.

al-Ghazali, al-Imam Abu Hamid Muhammad ibn al-Ghazali. (1988). Ihya' Ulumuddin Jiwa Agama.Terj.Tk. Hj Ismail Yaakub Sh. Kuala Lumpur: Victory Ajensi.

Al-Mahrooqi, R., Denman, C., Al-Siyabi, J. \& Al-Maamari, F. (2015). Characteristics of a Good EFL Teacher: Omani EFL Teacher and Student Perspectives. SAGE Open, 5(2). doi: $10.1177 / 2158244015584782$

Al-Marri, T. S. K., Oei, T. P. S., \& Al-Adawi, S. (2009).The development of the short Muslim practice and belief scale. Mental Health, Religion and Culture, 12 , (5), 415-426. doi: 10.1080/13674670802637643

Azimi Hamzah, Steven Eric Krauss@ Abdul Lateef Abdullah, Sidek Mohd Noah, Turiman Suandi, Rumaya Juhari, Jamiah Manap, Khairul Anwar Mastor, AzmaMahmoud \& Hasnan Kassan. (2006). Muslim Religiosity and Personality Indexing: Implications for Nation Building. Serdang: Institute for Social Science Studies Universiti Putra Malaysia.

Azma Mahmood. (2006). Pengukuran Tahap Penghayatan Pendidikan Islam Pelajar-Pelajar Sekolah Menengah di Malaysia. Tesis Ph.D Universiti Kebangsaan Malaysia. 
Bahagian Pengurusan Maklumat, Kementerian Pendidikan Malaysia (2014).

Bassili JN. (1996). The how and why of response latency measurement in telephone surveys. In Schwarz, N \& Sudman, S (eds). Answering Questions: Methodology for Determining Cognitive and Communicative Processes in Survey Research. San Francisco: Jossey-Bass Publishers, 319-46.

Czaja R \& Blair J. (1996). Designing Surveys: A guide to Decisions and Procedures. California: Pine Forge.

Darraz, M. A. (1973). Dustur al-Akhlaq fi al-Qur' an, Beirut: Muassasah al-Risalah.

Encyclopedia of Islam New Edition. (1979). H.A.R. Gibb, J.H Kramers, E. Levi-Provencal, J. Schachat. E.J. Brill:Leiden

Ensiklopedia Islam Safir. (2000). Terj, Hassan basri Awang, Mat Dahan, Abd. Halim Mohamad, Maheram Ahmad, Munif Zariruddin, Fikri Nordin dan Suhaimi Mohd Yusof. Kuala Lumpur: Dewan Bahasa dan Pustaka

Habibah@ Hartini Ramlie \& Zaharah Hussin. (2014). Profesionalisme Perguruan Pendidikan Islam Berasaskan Riadhah Ruhiyyah: satu analisa keperluan. The Online Journal of Islamic Education January, 2(1), 7-24. Retrieved from http://ojie.um.edu.my/filebank/published_article/6053/Article_2_V2_I1_Jan2014.pdf

Jimaain Safar. (2012). Pembinaan instrumen pentaksiran akhlak berasaskan rakan sebaya pelajar sekolah menengah. Tesis PhD Fakulti Pendidikan UKM

Kamarul Azmi Jasmi. (2010). Guru cemerlang pendidikan islam sekolah menengah. Tesis Dr. Fal, Fakulti Pendidikan, Universiti Kebangsaan Malaysia.

Kyllonen, P. C., Lipnevich, A. a., Burrus, J. \& Roberts, R. D. (2014). Personality, motivation, and college readiness: A prospectus for assessment and development. ETS Research Report Series, 2014(1), 1-48. doi:10.1002/ets2.12004

Latefah Alkanderi. (2001) Exploring education in Islam: al-Ghazali's model of the master-pupil relationship applied to educational relationship within the Islamic family. Thesis of $\mathrm{Ph}$. D. The Graduate Scholl of College of Education.

Mahony, P. (2009). Should 'ought' be taught? Teaching and Teacher Education, 25(7), 983e989

Md Idris, K., Bidin, Z., \& Saad, R. AJ. (2012). Ukuran nilai keagamaan dalam Islam dan hubungannya dengan gelagat kepatuhan zakat perniagaan.Jurnal Pengurusan. (34),

Mohd Aderi Che Noh, Khadijah Abdul Razak \& Ahmad Yunus. (2015). Islamic Education Based on Quran and Sunna during Prophet Muhammad 's Era and Its Relationship With Teenagers ' Moral Formation . Tinta Artikulasi Membina, 1(2). 3-10.

Mohammad Aziz Shah, Mohamed Arip, Aslina Ahmad, , Mohammad Nasir Bistamam, Martina Amira Azam, Siti Nur Sarah. (2015. Pembinaan Kesahan dan kebolehpercayaan Inventori Spiritual Imam alGhazali (ISIG). Jurnal Bitara Edisi Khas (Psikologi Kaunseling). Vol 82015

Mohd Nasir bin Omar. (2005). Akhlak dan Kaunseling Islam. Kuala Lumpur: Utusan Publication \& Distributors Sdn. Bhd.

Nasih Ulwan. (1989). Cet. Ke 3. Pendidikan Anak-Anak Dalam Islam. Jilid 2. Penterjemah : Saifullah Kamalie. Penyunting : ANwar Rasyidi. Kuala Lumpur ; Penerbit Darul Fikir

Nik Azis Nik Pa. (2012). Bab Sebelas : Pengembangan Nilai melalui Penulisan Tesis dan Disertasi. Dokumentasi akademik tidak diterbitkan, Universiti Malaya, Kuala Lumpur.

Salmah Kassim. (2004). Kualiti Perkhidmatan Guru di sekolah-sekolah menengah di daerah Pulau, Pulau Pinang. Tesis Sarjana Pendidikan UM 